DOI https://doi.org/10.30525/978-9934-26-004-9-8

\title{
АВТОРСЬКЕ ЮВЕЛІРСТВО ЯК ФАКТОР РОЗВИТКУ УКРАЇНСЬКОЇ КУЛЬТУРИ НА ПОЧАТКУ ХХІ СТ.
}

\author{
Кухтій О. С.
}

аспірант кафедри івент-менеджменту та індустрії дозвілля Київького національного університету культури і мистецтв

Федотова О. О.

доктор історичних наук, професор кафедри державного управління і права

Приватного вищого навчального закладу «Киїський університет культури»

м. Київ, Україна

Авторське ювелірство - це вид мистецтва, твори якого виступають втіленням творчої діяльності майстрів-професіоналів. Під дефініцією «авторське ювелірство» розуміємо самостійну, технологічно багатоетапну роботу певного майстра у процесі виготовлення ювелірного виробу в одиничному варіанті чи обмеженій кількості екземплярів. Зважаючи на унікальність та неповторність творів, вказаний напрям суттєво збагачує вітчизняну культуру цінними, з художньої точки зору, витворами мистецтва.

XXI століття характеризується активним впровадженням різного роду інновацій, і ювелірна справа не $\epsilon$ виключенням. Інновація у перекладі 3 латини означає - оновлення, відновлення, зміна; новостворені або удосконалені у виробництві технології [3]. Майстер-ювелір безпосередньо виступає реалізатором творіння, так званим авторомвиконавцем. Варто зазначити, що інноваціям притаманні такі ознаки: докорінні зміни у свідомості та поведінці учасників інноваційних перетворень, неприйняття та одночасна орієнтація на традиції, затребуваність ринковою економікою, масовий характер визнання нововведень [9]. Стосовно до того авторське ювелірство - приклад вдалого поєднання давніх культурно-мистецьких надбань 3 новітніми технологічними досягненнями.

Широкий спектр технічних можливостей, починаючи від процесів створення ескізу та креслення, які можна замінити 3D технологіями, a також застосування модернізованого обладнання, дозволяє ювелірумодельєру при виготовленні виробів суттєво скоротити час затраченої 32 
роботи. В результаті того митець витрачає набагато менше зусиль, якість роботи збільшується, а сам виріб конструкційно ускладнюється. Саме тому сучасний майстер-ювелір повинен володіти знаннями 3 хімії, фізики, добре розбиратися у технологічних аспектах виготовлення, особливостях малюнку та дизайну виробів, технічному кресленні, огранюванні дорогоцінних та недорогоцінних каменів, бути обізнаним в матеріалах для виготовлення прикрас, знати історію ювелірної справи тощо. I це далеко не весь спектр його компетентностей. На підставі вказаного набору вмінь можна встановити в ювелірному виробі певні мистецько-стильові характеристики, притаманні індивідуальній манері виконання автора.

Інновації в ювелірній галузі - це знання, отримані в ході багаторічної праці та незліченної кількості експериментів. Позитивні результати роботи патентує Міністерство освіти і науки України та Державний департамент інтелектуальної власності. Серед українських ювелірів слід виокремити низку майстрів-новаторів впровадження у мистецьку практику оригінальних технологій. Скажімо, директор АТ Вінницького заводу «Кристал» А. Костельнюк у січні 2003 р. запатентував «спосіб виготовлення 89-гранного діаманту «Аріадна-89» [4, с. 1]. У свою чергу митець О. Тормосов 2009 р. отримав патент на виготовлення ювелірного виробу - пірсингову шпильку зі змінним кінцевим наголовником i шарнірним 3'єднанням [ 10 , с. 1]. Авторський колектив у складі В. Новіцького, К. Ігнатенка, Я. Кордіяки розробив спосіб виготовлення ювелірних виробів зі вставними елементами, що офіційно було зареєстровано 2011 р. [6, с. 1].

Відповідно до вказаного проблемного аспекту особливу увагу також варто приділити технологічній інновації, запатентованій 2012 p. T. Калюжною. Запропонований нею спосіб виготовлення ювелірних виробів передбачає з'єднання елементів за допомогою застосування спеціального клею для частин, виготовлених із декоративних матеріалів. Тобто, особливість даного способу полягає у тому, що «деталі ювелірного виробу використовують відшліфовані шматочки кам'яного вугілля» [5, с. 1].

Ювелірне мистецтво є формою матеріальної та духовної культури, пов'язаною зі здатність людини до естетичного сприйняття та відтворення картини власного світобачення за допомогою знань та образно-символічних засобів, основою чого стає творче начало митця. Відбувається процес культурної трансмісії, тобто « культура передається від попередніх поколінь до наступних через навчання» [8, с. 1]. Так, відомий ювелір-емальєр В. Дудніков передав свої знання донці 
Я. Паламарчук, яка освоїла складні техніки емалевого живопису по гільйоше, ліможську мініатюру, портретний емалевий живопис.

Наступний діяч, I. Карпов, досвідом оволодіння професійними навичками завдячує своїй матері, I. Карповій, з якою разом очолює ювелірну компанію «Karpov\& Karpova Jewellery». Використовуючи такі матеріали, як золото, ебенове дерево, бурштин, діаманти майстри створили чудову колекцію авторських прикрас. Вчений-культуролог Д. Беррі називає цей вид трансмісії - вертикальним [8, с. 2], оскільки його репрезентують декілька поколінь ювелірів, які надалі передаватимуть набуті знання своїм нащадкам.

Існує також інший вид трансмісії, запропонований згаданим вище дослідником, що має назву горизонтального, коли автор самостійно здобуває та удосконалює власний досвід. Наприклад, брати Кочути, не маючи спеціальної освіти за даним профілем, високі професійні навички в ювелірній галузі сформували шляхом застосування експериментального методу. На сьогодні твори майстрів займають достойне місце у культурному надбанні України.

У свою чергу отримані автором-митцем знання у спеціальних навчальних закладах є ознакою так званої «непрямої» трансмісії $[8$, с. 2]. До них можна віднести такі вітчизняні установи 3 різним рівнем акредитації: Навчально-виробничий центр «Академія ювелірного мистецтва» (м. Одеса), Державний професійно-навчальний заклад «Міжрегіональний центр ювелірного мистецтва м. Києва», Вижницький коледж прикладного мистецтва ім. В. Шкрібляка (Чернівецька область), Львівський державний коледж декоративного і ужиткового мистецтва ім. I. Труша; заклади вищої освіти, на базі яких створено окремі кафедри або запроваджене навчання за дотичними до вказаного профілю спеціальностями (Львівська національна академія мистецтв, Косівський інститут прикладного і декоративного мистецтва, Київський державний інститут декоративно-прикладного мистецтва і дизайну ім. М. Бойчука, Закарпатський художній інститут, Київський національний університет технологій та дизайну та ін. [2]. Серед їх випускників необхідно згадати: Д. Мамчур, О. Барбалата [1], С. Вольського, В. Качмара, А. Сокол, М. Котельницьку, М. Столяра та ін. діячів [7].

Отже, на підставі проведеного дослідження можна підвести підсумок, що ювелірне мистецтво $є$ потужним фактором розвитку вітчизняної культури. Активне застосування інновацій у ювелірних технологіях сприяє вдосконаленню ювелірної майстерності. Використання дефініції «культурна трансмісія» в авторському ювелірстві дозволяє розглянути дану галузь як на підставі урахування набутого досвіду в ході передання 
знань між поколіннями, так і в процесі індивідуального оволодіння ними за допомогою багаторазових експериментів та нововведень.

\section{Література:}

1. Луць С. Ювелірне мистецтво України на зламі XX - XXI ст.: генезис поступу. Деміург: ідеї, технології, перспективи дизайну. 2019. Т. 2, № 1. С. 93-111.

2. Пасічник Л. В. Ювелірне мистецтво України XX-XXI століть. Проект «Наукова книга» (Молоді Вчені) : [монографія] / Наук. ред. Г. А. Скрипник. Нац. акад. наук України, Ін-т мистецтвознавства, фольклористики та етнології ім. М. Т. Рильського. Київ : Наукова думка, 2017. 299 [5] с. : фот.

3. Словник іншомовних слів. Уклад.: С. М. Морозов, Л. М. Шкарапута. Київ: Наукова думка, 2000. 680 с.

4. Спосіб виготовлення 89-гранного діаманту «АРІАДНА-89»: пат.53443 Україна. №2002054335; заявл.27.05.2002; опубл.15.01.2003, Бюл. №1. URL: https://uapatents.com/5-53443-sposib-vigotovlennya-89grannogo-diamantu-ariadna-89.html

5. Спосіб виготовлення ювелірних виробів: пат. 69923 Україна. №201105882; заявл.11.05.2011; опубл.25.05.2012, Бюл. № 10. URL: https://uapatents.com/4-69923-sposib-vigotovlennya-yuvelirnikh-virobiv.html

6. Спосіб виготовлення ювелірних виробів зі вставними елементами: пат. 94201 Україна. № 201012314; заявл.18.10.2010; опубл.11.04.2011, Бюл. №7. URL: https://uapatents.com/3-94201-sposib-vigotovlennyayuvelirnikh-virobiv-zi-vstavnimi-elementami.html

7. Чегусова 3. А. Декоративне мистецтво України кінця XX століття. 200 імен: Альбом-каталог. Київ: ЗАТ «Атлант ЮЕмСі», 2002. 511 с.

8. Черепова А. А. Междисциплинарный подход к определению понятия «Культурная трансмиссия». Режим доступу: https://cyberleninka.ru/article/n/mezhdistsiplinarnyy-podhod-k-opredeleniyuponyatiya-kulturnaya-transmissiya/viewer

9. Шаронова С. А. Социальные технологии: деловые игры. Учебное пособие. М.: Издательство ПСТГУ, 2013. 224 с.

10. Ювелірний виріб: пат. 39138 Україна. № 200809872; заявл. 29.07.2008; опубл.10.02.2009, Бюл. №3. URL: https://uapatents.com/239138-yuvelirnijj-virib.html 